
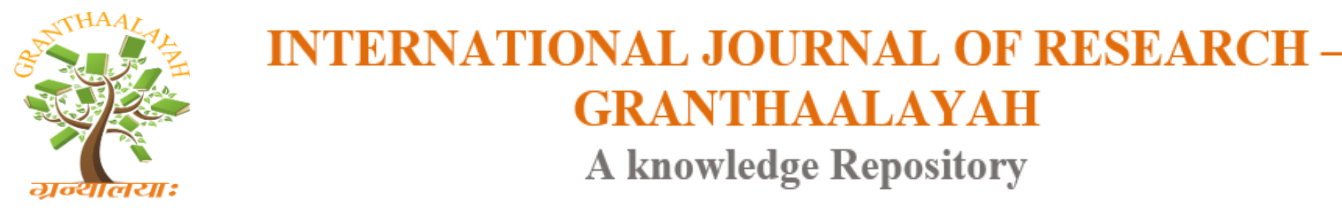

Management

\title{
THE EFFECT OF MACROECONOMIC DETERMINANTS OF STOCK PRICE MOVEMENTS IN NIGERIA
}

\author{
Chris O. Udoka ${ }^{1}$, Mfon Joseph Nya ${ }^{2}$, James Godwin Bassey ${ }^{3}$ \\ ${ }^{1}$ Ph.D, MAMN, Department of Banking and Finance, Faculty of Management Sciences, Calabar \\ - Nigeria \\ ${ }^{2,3}$ M.Sc (Finance), Department of Banking and Finance, Faculty of Management Sciences, \\ Calabar - Nigeria
}

\begin{abstract}
This study examined the effect of macroeconomic determinants of stock price movements in Nigeria. To achieve this objective, data were gathered on macroeconomic variables such as gross domestic product, exchange rate, inflation, interest rate and absolute stock price were captured for the purpose of analysis. The autoregressive distributive lag (ARDL) model was used in analyzing the macroeconomic determinants of stock price movement in Nigeria. The augmented Dickey-Fuller (ADF) unit root test was also engaged in order to ascertain the stationarity or otherwise of the variables. The ADF unit root test revealed that only interest rate was stationary at levels while the remaining variables became stationary when differenced once. The ARDL findings revealed that the determinants variables (GDP, EXCHR, INTR, and INFL) were not jointly co-integrated with the dependent variable, ASTP, hence, no existence of a long run relationship. Conclusively, there was no long run relationship between macroeconomic determinants and stock price movements in Nigeria. It was recommended that, government should create conducive business environment, strengthen the real sector to stimulate the economy, boost savings and stock investment. Finally, government should fine tune its policies on exchange rate determination and setup a consistent policy plan to stimulate investment in the capital market.
\end{abstract}

Keywords: Absolute Stock Price; Gross Domestic Product; Exchange Rate; Efficient Market Hypothesis.

Cite This Article: Chris O. Udoka, Mfon Joseph Nya and James Godwin Bassey. (2018). "THE EFFECT OF MACROECONOMIC DETERMINANTS OF STOCK PRICE MOVEMENTS IN NIGERIA." International Journal of Research - Granthaalayah, 6(1), 203-218. https://doi.org/10.29121/granthaalayah.v6.i1.2018.1609.

\section{Introduction}

Emerging market like Nigeria is characterized by high volatility and inherent dynamics which are a reflection of the stock price movement on the Nigerian Stock Exchange (NSE) floor. Since 
after the 2007/2008 global economic crisis, the stock market has faced a substantial fluctuation and shock that emanates from the subprime mortgage crisis in U.S. This is a proof that the Nigerian stock market had significantly responded to movements in exchange rate, global oil price changes and other macroeconomic uncertainties between 2010 and 2015 (Kelikume, 2009). Udoka, Mboto and Anyingang (2013) collaborated this fact when they noted that, changes in oil price affects markets for foreign exchange, brings about stock exchange panics, high inflationary rate, financial and monetary policy instability, and eventually, high interest rate. This has also had adverse effect on stock price movement in Nigeria. The Nigerian stock market has maintained inconsistent changes that have resulted in capital depreciations and low returns on investment across all sectors of the economy. As activities in the capital market declines continuously and the pressure of sales being high, the participants in the market have linked this trend to panic and dearth of adequate information while others opined that government economic policy and the plunge in oil price is the formidable cause.

According to Soludo (2004), there is a high level of volatility in stock prices as a result of the fluctuations in the market, especially as the pressure aimed at interest rate control towards market prices are most likely to reflect funds scarcity and inflation. The investors and public confidence will be engineered if the efficiency of the market is operational, and they will part with their funds willingly into security investments with the confidence of earning high returns (Udoka \& Anyingang, 2014). The stock market does not operate in isolation; the market reacts to factors within and outside the economic system such as global events, government economic policies, changes in regulatory environment, and instability in political climate which poses negative influence to business and investing community. Nyong (2007) opined that, stock prices affect cost of capital since stock price increment will result in a rise in the firm's value in relation to its share capital replacement cost. Subsequently, this gave rise to increased expenditure on investment and higher aggregated economic yield as a result of firms becoming capable to generate funds for investment expenditures. With this stance, many researchers have examined the importance of the operations of stock market and financial institutions' collaborative part in stock price determination.

According to Rouseau and Wachtel (2000), three key factors are adduced for the importance of financial institutions on stock market. They include: (1) the provision of potential exit mechanism for entrepreneurs and investor by equity markets (2) portfolio investment and foreign direct investment inflows are potentially critical investment fund sources for transiting economies and emerging markets. (3) Liquidity provision via organized exchanges drives both domestic and foreign investors to invest in long term assets where funds can now be available for large projects financing and indivisible investment that facilitates large scale economies. If these incentives are unavailable, investors are faced with the problems of increased uncertainties, reduced investors incentives and participants exposure to high research in an attempt to predicting the behavior of the future of the market. The concern of stock prices being predicted or not by macroeconomic variables is of great concern to both practitioners as well as academics globally (Chukwuma-Agu, 2009). This approach suggested that, the movement in stock price is occasioned by interest rate, inflation rate, exchange rate, economic growth, etc. Hence, the primary interest of this study was to examine the determinants of stock price movement in Nigeria from 1986- 2014. 
The fiscal sector contraction brought about private sector credit crowding-out and impacted negatively on the capital market thereby affecting stock investment. The internal management crisis and the absence of effective supervision and regulation on the part of the regulators have slowed down the recovery of Nigerian capital market development. Ineffective regulatory surveillance by Security and Exchange Commission (SEC) and the NSE, and high transaction cost has also affected investors' confidence in the market.

Major global events throughout the world such as political unrest and insecurity have influenced investors' confidence and also have an impact on stock prices. This factor influences what they do with their money as no investor will like to invest in an unstable political environment. In spite of all these, the Nigerian capital market still has good prospect; the reduction in costs of transaction, publication of periodic forecasts of quoted companies, strict regulatory surveillance by both the SEC and NSE that would reinforce investors' confidence in the market, and resolving of all internal management crises are necessary to ensure efficient and robust capital market. In view of the above scenario, the purpose of this study is four-fold, namely, to:

1) Determine the effect of Gross domestic product on stock price movement;

2) Ascertain the effect of Exchange rate on stock price movement;

3) Show the linkage between inflation and stock price movement;

4) Assess the impact of interest rate on stock price movement.

For simplicity and ease of comprehension, this paper is divided into five sections. Section one is the introduction. It dwells on the importance of the operations of stock market and financial institutions' collaborative part in stock price determination. Section two delves into the literature review, enunciating recent position of scholars on stock price movement. Section three is the methodology while section four; data obtained are presented, analyzed and tested for informed judgment. Section five is the final section and dwells on emerging findings arising from the discussion of the paper for operational and technical considerations.

\section{Theoretical Underpinnings/Literature Review}

The efficient market hypothesis is the theoretical base adopted for this study. This hypothesis was developed by Fama in the early 1960s. Fama's knowledge in finance and macroeconomics assisted him to hypothesized that the market is transparent, that is, information efficient. He stated that, a capital market is deemed efficient at a point where all information available is reflected fully in security prices. Indeed, an efficient market is a critical element of a capitalist system. In a capitalist system, the prices in the markets are the major indicators of efficient allocation of financial resources. That is, when securities are being issued by companies in order to finance their operations, fair prices are expected and when investors selects from these securities which afford them the right of ownership, their assumptions are that these prices are fair enough. If efficient allocation is the core of the capital market, securities price must be the measuring indicator of value (Ogege \& Udoka, 2012).

Additionally, Nyong (2007) argued that, stock market efficiency is a condition critical for the Nigerian economic growth. The EMH is the theoretical underpinning for the development of share price random walk character. This assumes a market where investors are well-informed and operates logically. A market is considered efficient when profit-maximizers that are 
competitive and rational are working together to determine the individual securities' market value in the future where current critical information is available almost free to market operators. In an efficient market, it is very obvious that, the existing market competition among smart participants will results to a position where the exact individual security price will be a true reflection of the influence of information based on both present and past events and what the market expects the future trends to become (Udoka, 2012).

According to Fama (1991), at any point under the efficient market, the actual price of security is the benchmark used in estimating its intrinsic value. Thus, the organizers and participants in the market worked with this information and share prices are adjusted gradually to a point where future profit opportunities are available. According to Tobin (2009), this is known as, information arbitrage efficiency. This refers to the market's ability of information processing in order to derive best advantages. In fact, all through the early periods of market efficiency awareness, relatively little attention was paid by financial analysts to the issues of widespread use of fixed commission and freedom of entry. Not until 1975 (New York) and 1986 (London) where these practices abandoned, in two of the global informational acknowledged market efficiency. During this period, many capital markets operational efficiency was appealing as evidence by failures of settlement in the back office problems faced in late $60 \mathrm{~s}$ and $80 \mathrm{~s}$ in London (Foley, 1991).

Another characteristic of a stock market that is efficient is that returns on stocks expected should equate interest rate and remain constant. According to Udoka (2012), new information regarding future profits lead the returns on stocks to be at variance to interest rate. More so, a market is efficient when the actual returns are different from the expected returns. It is still the expectations of the investors that future returns should equate the real interest rate and remain constant. On the other hand, if prices increase beyond expectations, it should not be the expectation of the investors that it will remain on the rise due to previous knowledge. Neither should they expect prices to decline in a manner that would offset the unexpected increase. The level of efficiency is dependent of the degree of disclosure of available information and the speed of processing information received by the market and reflected in the prices of shares. However, no market can be said to be perfectly efficient in reality (Osei (2002).

The concept of an efficient market merely represents an idea against which real markets can be compared. Olowe (2007), Fama (1970), Khoury (1983) viewed the concept of the efficiency of the capital market from its roles is expected in the economy which is categorized as:

1) Allocation efficiency: the existence of the primary market allocative efficiency is relied on secondary market existence and efficiency in all regards (Mbat, 2001).

2) Operational efficiency: this is made possible if the intermediaries in the market operate at a point where the channeling of financial resources to productive use is done at minimum cost and with fair return for such services. (Copeland \& Weston, 1983; Olowe, 2007). Operational efficiency of stock market in Nigeria is core duty of the regulatory institutions which has the Nigerian Securities and Exchange Commission (NSEC) as its apex regulatory body (Udoka, 2013).

3) Pricing efficiency: here, prices are used in the market as an indicator for the allocation of capital. The forces of demand and supply are the determining factor for price. A price 
efficient market is one where the reprocessing of information is carried out efficiently (Fama, 1970; Khoury, 1983).

According to Fama (1970), the appropriate evaluation of all available information at all time is the basis for capital assets prices. Howbeit, research in finance revealed that emphasis has been placed on pricing efficiency though it is allocation and operational efficiency off shoot (Copeland \& Weston, 1983; Baumol, 1965; Olowe, 2007). Formally, the study defines the efficiency of the capital market as a market where the prices of securities fully reflects quickly, all known information. In an efficient market, all schemes aimed at outperformed the market are futile. No devised scheme by a market participant should lead to higher returns consistently than those derive on a hold and buy strategy. A given level of risk and same return rate should be realized by all investors in any efficient market. No participant or group's action should influence security prices in the market (Khoury, 1983).

Studies in advanced nations have revealed that, prices of stock are key growth indicator of an economy. Due to its leading role as a measure to business cycles indicator, majority of the studies have been carried out in the economy of United States. The Dow Jones composite index of the prices of stock is one of U.S leading economic indicators for over seventy years according to Mitchell and Burns (1998). Other developed economies becoming more dominance in literature and widely adopted. In the African economies, leading indicators are quite rare and many of the African literatures are dependent on advanced economies.

According to Attari and Safdar (2013), literatures in African stock markets concentrated on the essence of stock market development, proxied by market capitalization to economic growth ratio. Damirguc-kunt and Levine (1996) in their study of stock price and determining factors in Kenya in 1996 investigated the stock price development consistency with the growth of the economy and financial intermediaries and also the financial intermediation harmonization with the nature of stock market development with some empirical evidence. Their findings revealed that:

1) Cross country regression on growth was employed and showed that stock market development predetermined component was positive and associated robustly with growth in the long run.

2) The cross country analysis further revealed that the level of stock market development correlated positively with financial intermediaries' development and economic growth consequently.

3) While the substitution of equity for debt finance is induced by stock market development in advanced economies, debt financing is facilitated more in least developed economies. Recommendation was made that strong financial institution to serve as intermediaries is necessary for stock market effectiveness.

Seyyed (2010) in his study of the emerging stock market performance and the Iranian economic growth in 2010, showed empirical examination of the linkage between the variables within the vector autoregressive (VAR) model. He argued that the main reason behind movement in stock prices is macroeconomic activity in the long run and the leading role played by stock market as critical economic indicator of the growth of the economy of Iran in the future in the short run. 
According to Foley (1991) who studied the role played by the Karachi stock market in facilitating the stock market development in Pakistan, engaged the Granger causality method and submitted the absence of any relationship among the variables used. They recommended that government of Pakistan should be more interested in political stability of the nation which they identified as a key determinant in order to achieve significant growth in gross domestic product. Raju and Ghosh (2004) made effort to calculate stock price volatility for various countries and concluded that stock market volatility is higher both in Indian and Chinese compared to other emerging economies.

According to Wang (2010) who studied the relationship that existed between stock market volatility and the volatility of macroeconomic variables in China by employing the lagaugmented VAR and generalized autoregressive conditional hereoskedasticity (GARCH) models revealed that, a bilateral relationship exist between stock prices and inflation. Further analysis showed that the existing association between real GDP and prices of stock was insignificant while stock prices and interest rate had a uni-directional relationship. Their recommendation was that government should be more sensitive to inflationary tendencies when formulating fiscal and monetary policies.

A study on selective power estimation of selected macroeconomic variables was carried out by Gupta and Modise (2011) for South Africa. Their result showed that, money supply, growth in oil production and interest rate have some predictive power for in-sample forecast in the short run while money supply and interest rate for out-sample forecast have predictability in the short run. Also, inflation exhibited strong predictive power for out-sample forecast and rightly recommend a balance between money market and capital market instruments. Chinzara (2014) also carried out a study of macro-economic uncertainty and volatility of the stock market in South Africa. He submitted that macroeconomic uncertainty affected significantly on the volatility of the stock market, while stock market volatility is widen by financial crisis.

Looking carefully in Nigeria, Udoka, Mboto and Anyingang (2013) carried out a study on asymmetric impact of shocks in oil prices on exchange rate volatility and domestic investment in Nigeria. Their result using elaborate econometric analysis showed that, industrial production, private investment and public investment showed negative response to oil price shock. This also demonstrated that macroeconomic variables determine stock price movement to a very large extent. Nurudeen (2002) researched on whether development in the price of stock raises the Nigerian economic growth by using ECM techniques. The findings revealed that, stock market development increased the Nigerian economic growth.

Similarly, Ekineh (2014) assessed the long run and the short run effect of the price of stock on the growth of the Nigerian economy. The findings revealed that, stock market development in relation to stock price impacts positively on the Nigerian economic growth in the long run and the short run. Ibrahim and Aziz (2013) investigated the cointegration between combined macroeconomic variables and movement in the price of stock. They exposed a cointegration between aggregate credit, general price level and official reserves (combined macroeconomic variables) and share price, and further found that, exchange rate is a critical determinant of movement of share price in the short run. These findings are in tune with Ibrahim (2013) who 
revealed the existence of long run association between share price and these variables and their statistical significance in the short run.

\subsection{Efficiency of the Nigerian Stock Exchange Market}

Udoka (2012), Mikailu and Sandra (2007) and Olowe (2007) revealed that the weak form efficiency is present in the Nigerian stock market while Smith (2002) in a study of stock markets in Africa do not see the evidence of random walk hypothesis in Nigeria. Very few studies have been associated with the Nigerian stock market efficiency (Udoka, 2012; Olowe, 2007; Ayadi, 1983; Samuel and Jacout, 1981). According to Olowe (2007), the first study on the Nigerian stock market efficiency was carried out by Samuel and Jacout (1981). Weekly prices of shares were used in the estimation of serial correlation coefficients of about 21 firms quoted on the Nigerian stock exchange from July 1978 to 1979, July. The study established a trace of dependence with one week lag in 7 firms only and with two lags in about 4 firms only. They concluded that, the weak for efficiency is evidence in the Nigerian stock market.

Ayadi (1983) employed non-parametric analysis to test the hypothesis that, changes in weekly successive price are independent in about thirty firms quoted on the floor of the Nigerian stock exchange from 1977, January to December, 1980. His findings revealed that83.3 per cent of about sixteen quoted firms are in tune with hypothesis that, successive changes in price is independent, and hence, the presence of the weak form hypothesis. Olowe (2007) also supported the findings of Ayadi (1983) and Samuel and Jacout (1981). The effect of the evidence is that technical analysis or other analysis of security is as a result of historical prices seem not to be valued in Nigerian security price but found to constantly adjusting to historical price information. According to Udoka (2012) who assessed the dynamics of the Nigerian stock market operational efficiency from 1986 to 2010 revealed that, the market was operationally weak-form efficient. This made him to recommend that, conducive macroeconomic environment should be government top priority in order for the private sector to drive the economy on the track of growth, development and sustainability. Researchers are generally of the view that, the stock market in Nigeria is of the weak form efficient on the premise that, analysis accommodates critical market indicators.

This according to Alile and Anao (2015) and Odife (2009) suggested that, investors that are well informed could predict future prices of stock using past information, hence, benefitting from price differentials. During the democratic transition of power in Nigeria in 1999, the Nigerian stock market witnessed some slight improvement in efficiency. This transition in power afforded most investors the confidence required to invest in the market. The enactment of the Privatization and Commercialization Act in 1999 and the establishment of the automated trading system (ATS) were few of the policy thrusts that revived the efficiency of the market.

\subsection{Determinants of Stock Price Movement}

Undoubtedly, the relationship between macroeconomic variables and equity market has been indeterminate. Prices of equity generally are meant to follow after macroeconomic variable known as fundamentals with no regards to other variables. Over times, the frontier of academic 
discussion has been the changing relationships between movement in equity prices and macroeconomic variables.

Schumpeter (1912) suggested that, there exist a strong association between development financial intermediaries of a country and the growth rate which represent the supply side. He suggested that financial sector service provision are very critical for the growth of the economy, since capital is allocated to the highest value that has no substantial risk of loss through transaction cost, adverse selection or moral hazards. Based on the basic financial theory, it is generally believed that, macroeconomic fundamentals like inflation, exchange rate, interest rate and so on would influence the indices of equity market pricing (Campbell, 2006). Considering the supply movement in share prices is being affected by economic growth through the influence of the average cash flows real present value. The implication is that, countries with higher economic growth in a longer period would likely experience faster average growth earnings.

As such, the basic fundamental share valuation, prices of equity will rise to the investor's expectation of the higher future returns. On the demand side, economic growth sustenance is a situation whereby more wealth market asset investments will in turn drive the price of equity to rise in the long term (Tobin, 2009). It is evidence that, majority of the works on the impact of long term macroeconomic variables on the variability of the prices of equity have been focused on developed economies.

Few of them are: Asprem (1999) investigated European equity markets; Cheung (1998) examined U.S, Canada, Japan, Italy and Germany equity markets; Mukherjee and Naka (1995) examined the movement of Japanese equity price; while Fama (1991) examined equity market in the U.S. Vadyba (2009) applied Johansen vector error correction model to establish the relationship between real economic activities, money supply, inflation and other economic fundamentals and Japanese stock market. All these findings agreed on a common fact that, there is a presence of cointegration among the variables used and that stock market has significant effect on the relation.

While still on the analysis of advanced economies, Humpe and MacMillian (2005) investigated using a log-linear model the degree to which the movements in Japan and US stock market has been explained by macroeconomic variables. The findings revealed that, a per cent increase in US industrial production lad to 1.09 per cent increase in US stock prices whilst a per cent increase in industrial production in Japan facilitates a 0.2 per cent increase in Japanese stock prices. The striking significance of the study of advanced economies is the fact that, share price variability in the equity markets was accounted for by long term macroeconomic variables which influenced the future cash flows of firms and discount rate risk adjustment.

Gupta and Modise (2011) investigated the changing association between economic variables and stock price in six selected pacific nations of Australia, Hong Kong, Korea, Japan, Thailand and Malaysia employing data on a monthly basis on industrial production index, consumer price index and stock indices from January 1993 to December, 2000. The findings revealed that, there exists a long run association among and between variables in about four countries only (Australia, Korea, Japan and Hong Kong). Except for Thailand and Hong Kong, all countries exhibited some levels of correlations in the short run. Similarly, Copeland and Weston (1983) 
revealed the same results as above; and showed that, Malaysian economic activities and stock price had long run relationship both capital control pre and post periods.

On the other hand, Jaffe and Mandelker (1976); Nelson (1976) and Fama and Schwert (1977) revealed a negation association between stock prices and inflation. They argued that inflation rate to result in tightening economic policies which might increase the nominal risk-free rate and causes discount rate to rise in the valuation model. Wang (2010) argued that the reason for this is the nominal contracts that do not permit a firm's cost and revenues for immediate adjustments. There would be initial decrease in cash flows if there is an adjustment in input costs that exceeds rising inflation than prices of output. Alternatively, given the demand for money if money stock decreases, there will be a rise in interest rate which will result in the prices of equity falling as a result of increased discount rate on cash flows in the future.

Adam and Twenboah (2008) in assessing the West African region, investigated macroeconomic variables effect on Ghana's equity price movement. The study modeled variables such as inward foreign direct investment, rate of treasury bills, rate of exchange and consumer price index from 1991 to 2006 using the multivariate Johansen cointegration test and the techniques of innovation accounting. Further test of correlation between stated macroeconomic variables and stock market index was conducted and the findings revealed that, in the long run, the variables cointegrate amongst themselves in Ghana. Further analysis of the result revealed a significant relationship between exchange rate and inflation and movements in Ghana equity price in the short run while inflation and interest rate were significant in the long run as well (Odoko, 1998).

Another critical macroeconomic variable capable of influencing stock prices is macroeconomic environment proxied by fiscal and monetary policies. According to Friedman and Schwartz (1963), the relationship between stock returns and money supply would influence the aggregate economy and stock returns. As the growth of money supply increases over available liquidity, securities price is bound to be higher.

Empirically, a linkage between these variables was established by Kraft and Kraft (1977) and Hamburger and Kochin (1972) while no relation was found by Nozar and Taylor (1988) and Cooper (1974). From the perspective of the neoclassical, stocks are meant to hedge against the rate of inflation on technological progress, capital and land (Ross, 1976). It therefore implies that shares price must substantially rise to a point it can compensate the investors any loss emanating from high inflationary rate. This is possible since stock price will raise as prices of commodities rises. Also, the demand for bonds will increase, hence, causing a fall in interest rate in the long run to a rise in the prices of equity.

On the flip side, if the demand for money causes money stock to decrease, there will be a rise in interest rate which leads to a fall in the price of equity due to increased discount rate of cash flows in the future. Market liberalization can facilitate a significant influence, the theory however posited that, the possibility of market forces being reflected in stock market without any form of interferences from government or others, showed that very few barriers to investment and the investors' ability to predict the market and increased their potentials for greater profits. 
Henry (2015) in analyzing equity prices impact revealed that, in the presence of liberalization, there exist an average of 3.3 per cent abnormal returns will be made monthly as a result of the liberalization of the market. Away from the analysis pf advanced equity markets, Konstantinos and Spyrous (2001) and Baumol (1995) examined empirically on the effect of banking sector and stock market on the economic development of five emerging markets. The employed time series multivariate techniques to analyze the long run causality and trends between economic variables and stock prices and revealed that, equity market could be a useful source of financial tool in a liberalized economy.

In a similar finding, Demetri-Amatis and Luintel (2001) revealed that, a long run relationship exist between the development of stock market and growth of an economy. According to Maysami and Koh (2004), there exists a cointegrating association between money supply, inflation and growth with stock market changes in Singapore. Levine (1996) argued that the reason for this is that, under liberalization, increase in real investment can take place in a particular country. The openness of the market for global transactions and decreased controls impacts significantly on how commercial investment and projects are executed. With the presence of increased capital availability and lower cost of equity, the net present values of many projects shift either from negative to positive value or/and increasing the value which in turn facilitates the growth of the country's economy (Obadan, 2004).

\section{Research Methodology}

This reveals the strategy and structure of investigation concerned in order to obtain answer to research questions. The specific structure of this useful guide is described as a research design. Based on the existing theoretical and empirical literature, descriptive and exploratory designs were adopted to evaluate the macroeconomic determinants of stock price movement in Nigerian. Though stock price movement relationship has a general theoretical foundation, in our model, Average stock price (ASTP) is hypothesized to depend on interest rate (INTR), inflation rate (INFL), exchange rate (EXCHR) and gross domestic product (GDP). This model is specified in line with the error correction mechanism (ECM) which revealed the relationship between the dependent variable in response to the interactions of the independent variable. This is specifies as:

$\mathrm{ASTP}=\mathrm{f}(\mathrm{GDP}, \mathrm{EXCHR}, \mathrm{INFL}, \mathrm{INTR})$

Where:

ASTP $=$ Average Stock price

GDP $=$ Gross domestic product

$\mathrm{EXCHR}=$ Exchange rate

INTR=interest rate

$\mathrm{INFL}=$ Inflation rate

b0-b4= estimation parameters, $u t=$ error term

The autoregressive distributive lag (ARDL) model was used in analyzing the macroeconomic determinants of stock price movement in Nigeria. The unit root test was also engaged in order to ascertain the stationarity or non-stationarity of the variables. To do this, the study adopted the augmented Dickey-Fuller unit root test for test of stationarity while the long run association between variables was carried out with the Johansen cointegration techniques. 


$$
\begin{aligned}
& \Delta \operatorname{LogASTP}_{t}=\alpha_{0}+\sum_{k=1}^{n} \alpha_{1} \Delta \log G D P_{t}+\sum_{k=1}^{n} \alpha_{2} \Delta \log \operatorname{EXCHR}_{t}+\sum_{k=1}^{n} \alpha_{3} \Delta \operatorname{LogINTR}_{t}+ \\
& \sum_{k=1}^{n} \alpha_{4} \Delta I N F L_{t}+\mathrm{p} 1 \Delta \log G D P_{t-k}+\mathrm{p} 2^{\Delta \log E X C H R_{t-k}}+\mathrm{p} 3^{\Delta \log I N T R_{t-k}+\mathrm{p} 4^{\Delta I N F L_{t-k}} \mathrm{e}_{\mathrm{t}}}
\end{aligned}
$$

\section{Data Analysis and Discussion}

The regression of the ADF unit root test for the variables showed that, most of the variables of interest had no unit root trend at various critical levels mostly at one per cent level of significance. In other words, only one variable (LINTR) was stationary at levels, hence, its null hypothesis reject at the presence of a unit root. Further analysis of the ADF revealed that these variables (LASTP, LGDP, LEXCHR) became stationary at their first differences, hence; their null hypotheses is rejected. Finally, only INFL variable was found to stationary at second difference, thus null hypothesis is rejected at conventional significant levels. With the stationarity of the series, it is critical to seek for a long run relationship amongst and between the variables using the ARDL bound testing approach.

The essence of the Wald f-test (bound test) was to determine the joint significance of the parameter estimates in the model. In conducting the test, certain restrictions are imposed on the long run coefficient estimates of determination (LGDP, LEXCHR, LINTR, INFL) and stock price movement in Nigeria (LASTP). The result of the ARDL bound test upper and lower critical bounds are based on one, five and ten per cent level of significance. As such, the finding revealed that the determinants variables (LGDP, LEXCHR, LINTR, INFL) are not jointly cointegrated with the dependent variable, LASTP, hence, no existence of a long run relationship.

The f-stat calculated was 4.17. The value is lower than the ARDL upper critical bound value which is 5.61. The value revealed the absence of any long run relationship between determinants (LGDP, LEXCHR, LINTR, and INFL) and stock price movements in Nigeria (LASTP). The coefficient of multiple determination (R-squared) of about 0.7421 indicating that, about 74.21 per cent of changes of the stock price movements in Nigeria (LASTP) are caused by macroeconomic variables (determinants). The model is considered freed from the issue of normality, heteroscedasticity and serial correlation.

Hitherto, the ARDL bound test estimates showed that changes in the current lagged period of gross domestic product have an insignificant effect on the movement in stock prices in Nigeria in the current period. This does not lend support to Nyong (1997), Obadan (1995) and Inanga and Emenuga (1997) that a vibrant stock market may become a basis for measuring aggregated economic activity changes using the stock market index.

The result also revealed that changes in the previous lagged period of exchange rate level have positive but significant impact on the movements in stock prices in Nigeria and is found to be in contrast with the findings of Adjasi and Biekpe (2005). Further investigation of the results showed that changes in the previous logged period of interest rate impacted significantly on stock price in Nigeria in the current period. This position does not collaborate with the findings made by Zordan (2005), Arango (2002), and Jefferis and Okeahalam (2000). 
Finally, further findings showed that changes in the previous lagged period of inflation had an insignificant effect on stock price movement in Nigeria in the current period. The findings agree with Spyrou (2004).

\section{Summary of Findings and Recommendations}

\subsection{Summary of Findings}

This study centered on examining macroeconomic determinant of stock price movement in Nigeria. In meeting the stated objectives of this study, the descriptive statistics test, ADF unit root test, over-parameterized, parsimonious ECM test and the ARDL bound tests were employed in this study. From the results of these analyses, the following findings are summarized: gross domestic product is not a critical determinant of stock price movement in Nigeria.

The analyses further revealed that, exchange rate are sensitive to stock price movement in Nigeria. Inflation rate also does not significantly affect stock price movement in Nigeria. Lastly, changes in interest rate influences the direction of stock price movement in Nigeria.

\section{Recommendations}

Recommendations made in this study follows after its analyzes and findings. They are:

1) Government should create conducive business environment, strengthen the real sector to stimulate the economy, boost savings and stock investment.

2) Government should fine tune its policies on exchange rate determination and setup a consistent policy plan to stimulate investment in the capital market.

3) Central Bank of Nigeria (CBN) should focus on maintaining inflation rate that is considered reasonably low. This rate should not be capable of eroding stock gains.

4) Policy makers and the CBN should focus on interest rate changes in order to stimulate private sector investment in Nigeria.

\section{Appendices}

\begin{tabular}{|c|c|c|c|}
\hline \multicolumn{3}{|c|}{ Null Hypothesis: LGDP has a unit root } & \\
\hline \multicolumn{3}{|c|}{ Exogenous: Constant } & \\
\hline \multicolumn{4}{|c|}{ Lag Length: 0 (Automatic - based on SIC, maxlag=6) } \\
\hline & & t-Statistic & Prob.* \\
\hline \multicolumn{3}{|c|}{ Augmented Dickey-Fuller test statistic-1.647520 } & 0.4459 \\
\hline \multirow[t]{3}{*}{ Test critical values: } & $1 \%$ level & -3.689194 & \\
\hline & $5 \%$ level & -2.971853 & \\
\hline & $10 \%$ level & -2.625121 & \\
\hline \multicolumn{3}{|c|}{ *MacKinnon (1996) one-sided p-values. } & \\
\hline
\end{tabular}

\begin{tabular}{|c|c|c|}
\hline \multicolumn{2}{|c|}{ Null Hypothesis: D(LGDP) has a unit root } & \\
\hline Exogenous: Constant & & \\
\hline \multicolumn{3}{|c|}{ Lag Length: 0 (Automatic - based on SIC, maxlag=6) } \\
\hline & th-Statistic & Prob. \\
\hline
\end{tabular}




\begin{tabular}{|c|c|c|c|}
\hline & \\
\hline & & \begin{tabular}{l|l||l|l} 
Augmented Dickey-Fuller test statistic-5.084089 & 0.0003 \\
Test critical values: & $1 \%$ level & -3.699871 & \\
\end{tabular} \\
\hline & $5 \%$ level & $\mid-2.976263$ & \\
\hline & $10 \%$ level & $\mid-2.627420$ & \\
\hline \multicolumn{3}{|l|}{ MacKinnon (1996) } & \\
\hline
\end{tabular}

\begin{tabular}{|c|c|c|c|}
\hline \multicolumn{3}{|c|}{ Null Hypothesis: LINTR has a unit root } & \\
\hline \multicolumn{3}{|l|}{ Exogenous: Constant } & \\
\hline \multicolumn{4}{|c|}{ Lag Length: 0 (Automatic - based on SIC, maxlag=6) } \\
\hline & & t-Statistic & Prob.* \\
\hline \multicolumn{3}{|c|}{ Augmented Dickey-Fuller test statistic-4.853304 } & 0.0006 \\
\hline \multirow[t]{3}{*}{ Test critical values: } & $1 \%$ level & -3.689194 & \\
\hline & $5 \%$ level & -2.971853 & \\
\hline & $10 \%$ level & -2.625121 & \\
\hline \multicolumn{3}{|c|}{ *MacKinnon (1996) one-sided p-values. } & \\
\hline
\end{tabular}

\begin{tabular}{|c|c|c|c|}
\hline \multicolumn{3}{|c|}{ Null Hypothesis: LASTP has a unit root } & \\
\hline \multicolumn{3}{|l|}{ Exogenous: Constant } & \\
\hline \multicolumn{4}{|c|}{ Lag Length: 0 (Automatic - based on SIC, maxlag=6) } \\
\hline & & t-Statistic & Prob.* \\
\hline \multicolumn{3}{|c|}{ Augmented Dickey-Fuller test statistic-0.946942 } & 0.7577 \\
\hline \multirow[t]{3}{*}{ Test critical values: } & $1 \%$ level & -3.689194 & \\
\hline & $5 \%$ level & -2.971853 & \\
\hline & $10 \%$ level & -2.625121 & \\
\hline \multicolumn{3}{|c|}{ *MacKinnon (1996) one-sided p-values. } & \\
\hline
\end{tabular}

\begin{tabular}{|c|c|c|c|}
\hline \multicolumn{3}{|c|}{ Null Hypothesis: D(LASTP) has a unit root } & \\
\hline \multicolumn{3}{|c|}{ Exogenous: Constant } & \\
\hline \multicolumn{4}{|c|}{ Lag Length: 0 (Automatic - based on SIC, maxlag=6) } \\
\hline & & t-Statistic & Prob.* \\
\hline \multicolumn{2}{|c|}{ Augmented Dickey-Fuller test statistic. } & -4.353911 & 0.0021 \\
\hline \multirow[t]{3}{*}{ Test critical values: } & $1 \%$ level & -3.699871 & \\
\hline & $5 \%$ level & $\mid-2.976263$ & \\
\hline & $10 \%$ level & $\mid-2.627420$ & \\
\hline \multicolumn{3}{|c|}{ *MacKinnon (1996) one-sided p-values. } & \\
\hline
\end{tabular}

\begin{tabular}{|c|c|c|c|}
\hline \multicolumn{3}{|c|}{ Null Hypothesis: LEXCHR has a unit root } & \\
\hline \multicolumn{3}{|l|}{ Exogenous: Constant } & \\
\hline \multicolumn{4}{|c|}{ Lag Length: 0 (Automatic - based on SIC, maxlag=6) } \\
\hline & & t-Statistic & Prob.* \\
\hline \multicolumn{3}{|c|}{ Augmented Dickey-Fuller test statistic-2.623394 } & 0.1003 \\
\hline \multirow[t]{3}{*}{ Test critical values: } & $1 \%$ level & -3.689194 & \\
\hline & $5 \%$ level & -2.971853 & \\
\hline & $10 \%$ level & -2.625121 & \\
\hline \multicolumn{3}{|c|}{ *MacKinnon (1996) one-sided p-values. } & \\
\hline
\end{tabular}


Null Hypothesis: D(LEXCHR) has a unit root Exogenous: Constant

Lag Length: 0 (Automatic - based on SIC, maxlag=6)

\begin{tabular}{|l|l||l|l|}
\hline & & t-Statistic & Prob. \\
\hline Augmented Dickey-Fuller test statistic-5.287644 & 0.0002 \\
\hline Test critical values: & $1 \%$ level & -3.699871 & \\
\hline & $5 \%$ level & -2.976263 & \\
\hline & $10 \%$ level & -2.627420 & \\
\hline *MacKinnon (1996) one-sided p-values. & \\
\hline
\end{tabular}

Null Hypothesis: INFL has a unit root

Exogenous: Constant

Lag Length: 0 (Automatic - based on SIC, maxlag=6)

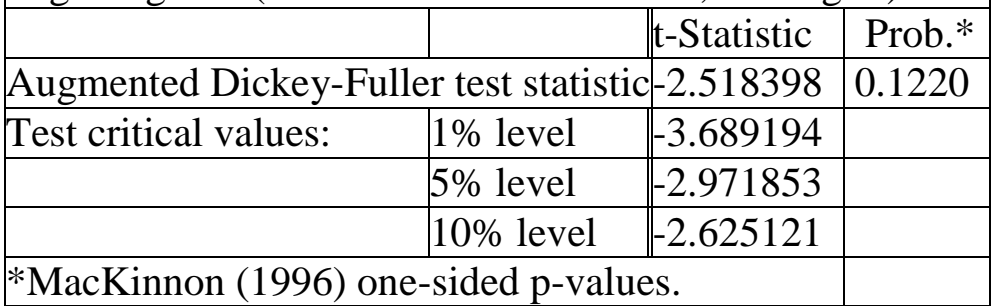

Null Hypothesis: D(INFL) has a unit root Exogenous: Constant

Lag Length: 4 (Automatic - based on SIC, maxlag=6)

\begin{tabular}{|l|l||c|c|}
\hline & & t-Statistic & Prob.* \\
\hline \multicolumn{2}{|l|}{ Augmented Dickey-Fuller test statistic } & -3.584589 & 0.0145 \\
\hline Test critical values: & $1 \%$ level & -3.752946 & \\
\hline & $5 \%$ level & -2.998064 & \\
\hline & $10 \%$ level & -2.638752 & \\
\hline \multicolumn{2}{|l|}{ *MacKinnon (1996) one-sided p-values. } & \\
\hline
\end{tabular}

Null Hypothesis: D(INFL,2) has a unit root Exogenous: Constant

Lag Length: 4 (Automatic - based on SIC, maxlag=6)

\begin{tabular}{|c|c|c|c|}
\hline \multicolumn{3}{|r|}{ t-Statistic } & Prob.* \\
\hline \multicolumn{3}{|c|}{ Augmented Dickey-Fuller test statistic-5.419232 } & 0.0002 \\
\hline \multirow[t]{3}{*}{ Test critical values: } & $1 \%$ level & -3.769597 & \\
\hline & $5 \%$ level & -3.004861 & \\
\hline & $10 \%$ level & -2.642242 & \\
\hline
\end{tabular}

ARDL BOUNDS TEST

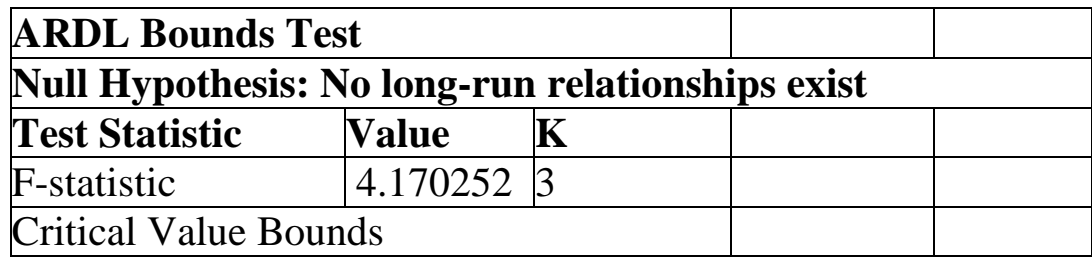




\begin{tabular}{|c|c|c|c|c|}
\hline Significance & I0 Bound & I1 Bound & & \\
\hline $10 \%$ & 2.72 & 3.77 & & \\
\hline $5 \%$ & 3.23 & 4.35 & & \\
\hline $2.5 \%$ & 3.69 & 4.89 & & \\
\hline $1 \%$ & 4.29 & 5.61 & & \\
\hline \multicolumn{5}{|l|}{ Test Equation: } \\
\hline \multicolumn{5}{|c|}{ Dependent Variable: D(LASTP) } \\
\hline \multicolumn{5}{|c|}{ Method: Least Squares } \\
\hline Variable & Coefficien & tStd. Error & t-Statistic & Prob. \\
\hline $\mathrm{D}(\operatorname{LASTP}(-1))$ & 0.728530 & 0.260145 & 2.800479 & 0.0160 \\
\hline D(LINTR) & -0.967724 & 1.375637 & -0.703473 & 0.4952 \\
\hline D(LINTR(-1)) & 3.030338 & 1.047103 & 2.894022 & 0.0135 \\
\hline D(LEXCHR) & 0.345688 & 0.650815 & 0.5 & 0.6050 \\
\hline D(LEXCHR(-1)) & -0.470538 & 0.514934 & -0.913784 & 0.3788 \\
\hline $\mathrm{D}(\operatorname{LEXCHR}(-2))$ & -1.182239 & 0.516232 & -2.290131 & 0.0409 \\
\hline $\mathrm{D}(\operatorname{LEXCHR}(-3))$ & -0.588353 & 0.615507 & -0.955884 & 0.3580 \\
\hline LGDP & -0.433529 & 0.317390 & -1.365919 & 0.1970 \\
\hline C & 23.76108 & 9.760379 & 2.434442 & 0.0315 \\
\hline LINTR(-1) & -6.526547 & 2.577684 & -2.531942 & 0.0263 \\
\hline INFL(-1) & -0.011259 & 0.015497 & -0.726563 & 0.4814 \\
\hline $\operatorname{LEXCHR}(-1)$ & 1.914498 & 0.703016 & 2.72 & 0.0185 \\
\hline LASTP(-1) & -1.244841 & 0.426121 & -2.921329 & 0.0128 \\
\hline R-squared & 0.742196 & \multicolumn{2}{|c|}{ Mean dependent var } & 0.272231 \\
\hline Adjusted R-squared & $\mathrm{d} 0.484392$ & \multicolumn{2}{|c|}{ S.D. dependent var } & 0.73858 \\
\hline S.E. of regression & 0.530350 & \multicolumn{2}{|c|}{ Akaike info criterion } & 1.875471 \\
\hline Sum squared resid & 3.375251 & \multicolumn{2}{|c|}{ Schwarz criterion } & 2.509286 \\
\hline Log likelihood & -10.44339 & \multirow{2}{*}{\multicolumn{2}{|c|}{$\begin{array}{l}\text { Hannan-Quinn criter. } \\
\text { Durbin-Watson stat }\end{array}$}} & 2.051264 \\
\hline F-statistic & 2.878915 & & & 2.49745 \\
\hline Prob(F-statistic) & 0.039606 & & & \\
\hline
\end{tabular}

\section{References}

[1] Adjasi K. \& Biekepe B. (2006), Stock exchange and economic growth: the case of selected African countries,

[2] University of Stellenbosch Business School, Cape Town, South Africa.

[3] Arango, L. E., Gonzalez, A. \& Posada, C. E. (2002). Returns and interest rate: A nonlinear relationship in the

[4] Bogotá stock market. Applied Financial Economics, 12(11), 835-842.

[5] Attari, J. I. \& Safdar, T. D. (2013). Macroeconomic variables and stock prices. A multivariate analysis. Africa Journal of Development Studies, 2(1), 159-164

[6] Chinzara, F. (2014). The element of banking in Nigeria. London: Graham Burn.

[7] Chukwuma-Agu, B. U. (2009). Fundamentals of finance ( $2^{\text {nd }}$ ed.). Uyo: Nelgrafik Press.

[8] Dermirgue, D. S.\& Levine, P. D. (2005). Sensitivity of investor reaction to market direction and volatility: dividend change announcements: Journal of Financial Research, 28(1) 21-41.

[9] Ekineh, O. I. (2014). The Nigerian capital market: Present and future challenges: Paper presented at a workshop on legislating for the capital market in a democratic environment organized by the Securities and Exchange Commission, Nicon Hilton Hotel, Abuja, Oct. 12. 
[10] Fama, E. F. (1997). Foundation of finance: portfolio decisions and security prices. Oxford: Basil Blackwell.

[11] Foley, B. J. (1991). Capital markets. Hong - Kong: Macmillan publishers.

[12] Gupta, M.O. \& Modise, A.S. (2011). Stock price and effective exchange rate of the dollar: Applied Economics, 24(5). 459-464.

[13] Ibrahim, D. E. \& Aziz, R. J. (2013). Security analysis and portfolio management. New Delhi: Pearson Education.

[14] Inanga, B. J. \& Emenuga, H. (2015). Capital market operators and their Functions. A paper presented at a Public Enlightenment Workshop on Opportunities in the Nigerian Capital Market for Industrial Development of Ekiti State of Nigeria and Teachers Forum.

[15] Jefferis, K. R. \& Okeahalam, C. C. (2000). The impact of economic fundamentals on stock markets in Southern Africa. Development Southern Africa, 17(1), 23-51.

[16] Kelikume, I. B. (2015). New evidence from the efficient market hypothesis for the Nigerian stock index using the wavelet unit root test approach: Proceedings of the Asia Pacific Conference on Business and Social Sciences, 2(7), 131-143.

[17] Mitchel, R. A. \& Burns, S. C. (1998). Principles of corporate finance. Retrived from http://ebookbrowse.com/principles-of-corporate-finance-brealey-myers-7th-ed-pdf-d138508468

[18] Nurudeen, E. T. (2002). Price volatility, expectations and monetary policy in Nigeria. Retrieved on 18/11/2009 from emmaadamgbe@yahoo.com

[19] Nyong, M. O. (2007). The stock market and economic efficiency. Uyo: Nelgrafik Press.

[20] Obadan, I. M. (2004). The information content of option prices and a test for market efficiency: Journal of Financial Economics, 6(1) 213-234.

[21] Ogege, S. \& Udoka, C. O (2012). The efficiency of the Nigerian stock exchange: A theoretical and empirical analysis. Indian Journal of Finance, 6(9), 13-20.

[22] Osei, K. I. (2002). Assets pricing and information efficiency of the Ghana stock market: Africa Economic Research Consortium Research Paper. 115, 1-15.

[23] Raju, T. R. \& Gosh, S. N. (2004). Stock market development and long-run growth: World Bank Policy Research Working Paper, 1582, $688-726$.

[24] Seyyed, T. U. (2010). Stock analysis for value investing: The price earnings ratio. Retrieved from http/www.stockmarketnigeria.com.

[25] Soludo, C. (2004). The politics of trade and industrial policy in Africa: forced consensus. Africa World Press.

[26] Spyrou, I. S. (2001). Stock returns and inflation: evidence from an emerging market. Applied Economics Letters, 8, 447-450.

[27] Tobin, P. G. (2009). Autoregressive conditional heteroskedasticity with estimates of the variance of United Kingdom inflation: Econometrica, 55(1), 391-407

[28] Udoka, C. O. (2012). Weak-form market efficiency: Dynamic effects of information on the Nigerian stock market': Interdisciplinary journal of Contemporary Research in Business, 4(7), 417-429.

[29] Udoka, C. O., Mboto, H. W. \& Anyingang, R. A. (2013). The effect of inflation on stock market performance in Nigeria: 1980-2010. International Journal of Marketing and Technology, 3(8), 1629

[30] Udoka, C. O. \& Anyingang, R. A. (2014). Operational Efficiency Dynamics of the Nigeria Stock Market: International journal of Finance \& Banking Studies, 3(1), 173-216.

[31] Wang, F. O. (2010). The random walk hypothesis and the behaviour of share prices in Nigeria: Nigeria Journal of Economic and Social Studies, 26(1), 57-71.

[32] Zordan, D. J. (2005). Stock Prices, Interest Rates, Investment Survival. Econometrica USA, Illinois. [Online] Available: http://www.econometricausa.com/publications/StockPrices.pdf

*Corresponding author.

E-mail address: udokaco@yahoo.com 